\title{
Genetic characterization of some rhizobial isolates from various legumes
}

\author{
Enas M. Abd El-Ghany, Ragaa A. Eissa, Abdelmegid I. Fahmi *, \\ HESHAM H. NAGATY, ABDELFATAH M. El-ZANaTy \\ Genetics Department, Faculty of Agriculture, Menoufia University, Egypt
}

\begin{abstract}
In the last few decades, there has been a growing interest in environmentally friendly sustainable agricultural practices, thus increasing the role of biofertilizers such as rhizobia, which can decrease the need for chemical fertilizers, reduce adverse environmental effects, and help to save money. Therefore, information on the distribution and genetic variation of native rhizobial isolates would aid in selecting novel rhizobial strains that could be developed and used as biofertilizers in legume production. This research was conducted to characterize 24 rhizobial isolates from five legumes on morphological, biochemical, and molecular aspects and determine the phylogenetic relationships among them. Rhizobial isolates were obtained from five Egyptian legumes: faba bean, lentil, pea, clover, and soybean. Morphological characterization classified the isolates into fast and slow growers. Biochemical characterization using API 20E and API 20NE systems showed a large diversity, which may reflect their adaptation in different environments. Moreover, molecular detection of the 16S rRNA gene enabled to characterize 19 of them to the species level. Rhizobial isolates from pea, faba bean, clover, and lentil were identified as Rhizobium leguminosarum and those from soybean were identified as Bradyrhizobium japonicum. These data reflected a narrow diversity of rhizobial species in Egypt. A phylogenetic analysis of the 19 isolates confirmed that $B$. japonicum isolates were divergent from all other isolates. Furthermore, the phylogram revealed that each group of isolates that originated from the root nodule of a certain legume formed a separate subcluster. The obtained data suggested a narrow range of interspecies variations, which is consistent with the idea of the presence of biovars among the species.
\end{abstract}

Key words: rhizobia, morphological, API 20E and API 20NE, 16S rRNA, phylogenetic

\section{Introduction}

Rhizobia are gram-negative bacteria present in the root nodules of legumes (Ngakou et al., 2009). These soil bacteria are aerobic, nonsporulating, and rod-shaped (Chaintreuil et al., 2000). A symbiotic relationship termed mutualism develops between legumes and rhizobia, wherein both organisms benefit from each other. Rhizobia produce nitrogen-containing ammonium which, unlike nitrogen in the air, can be easily taken up by plants and used for protein production (Kiers et al., 2002). Therefore, symbiotic nitrogen fixation resulting from a rhizobia-legume interaction can act as a renewable source of nitrogen and replace the usage of nitrogenbased chemical fertilizers (Mus et al., 2016). The inter- action between rhizobia and plants leads to the establishment of specialized structures called nodules in which bacteria convert atmospheric nitrogen into ammonia.

The legume family (Leguminosae, Fabaceae) consists of approximately 19300 plant species, which includes approximately 750 genera. This family of flowering plants includes species of agronomic importance such as faba bean (Vicia faba), clover (Trifolium alexandrinum), soybean (Glycine max), pea (Pisum sativum), and lentil (Lens culinaris). In the last few decades, there has been a growing interest in environmentally friendly sustainable agricultural practices, thus increasing the role of biofertilizers such as rhizobia, which can decrease the need for chemical fertilizers and thus reduce adverse

\footnotetext{
* Corresponding author: Genetics Department, Faculty of Agriculture, Menoufia University, Shebin El-Kom, Egypt; e-mail: abdelmageed.fahmy@agr.menofia.edu.eg
} 
negative environmental effects and help to save money. Therefore, information on the distribution and genetic variation of native rhizobial isolates would aid in selecting novel rhizobial strains that could be developed and used as biofertilizers in legume production (Eissa et al., 2009; Hassan et al., 2015). Rhizobia-legume symbiosis is of special importance for agricultural ecosystems, annually producing $50 \%$ of the total biological nitrogen fixation worldwide (Yadav and Verma, 2014). Rhizobia-legume symbiosis is a host-specific association, and hence, there is a need to determine the strains and the diversity of rhizobia associated with a specific type of legume for better utilization of the benefits associated with rhizobia biofertilizers (Batista et al., 2015). Rhizobia distribution and its diversity are also affected greatly by the geographical locality, and therefore, determining their phylogeny could highlight their evolutionary origin. Efficient methods of classifying isolates are necessary to identify strains with a high nitrogen fixation ability. The initial characterization and screening of rhizobia have been based on morphological features; however, this method is highly prone to errors due to morphological plasticity. Rhizobia are also specific to a particular legume; therefore, it is essential to identify and characterize these organisms by morphological, biochemical, and molecular methods to detect the best and most efficient isolates for nitrogen fixation. Bacteria possess ribosomal RNA (rRNA) cistron that comprises three genes: a small subunit $16 \mathrm{~S}$ and large subunits $23 \mathrm{~S}$ and $5 \mathrm{~S}$. The relationship among closely related groups such as species or genera can be determined by genetic sequence information, which is widely regarded as one of the most valid criteria (Litvaitis, 2002; Casamatta et al., 2005; Rajaniemi et al., 2005; Svenning and Wright, 2005). Hence, phylogenetic studies can be performed by comparing $16 \mathrm{~S}$ rRNA. Therefore, the main objective of this study was characterization of rhizobial isolates from some legumes growing in Egypt on morphological, biochemical, and molecular levels and determination of the phylogenetic relationships among them.

\section{Materials and methods}

\section{Root nodule collection}

Plants of five field-grown legume species, namely faba bean ( $V$. faba), clover ( $T$. alexandrinum), pea ( $P$. sativum), lentil (L. culinaris), and soybean $(G . \max )$, were collected at various field locations in seven governorates in Egypt: Menoufia, Gharbia, Suez, Dakahlia, Giza, Fayoum, and Behyra. At each location, 10 individuals of each legume species were sampled. The plants along with their rhizosphere soil were kept in plastic bags and brought to the laboratory where bacterial strains were isolated (Jordan, 1984).

\section{Bacterial isolation}

Root nodules were washed with tap water twice to remove soil. The nodules were surface sterilized using 95\% alcohol for 1-4 min, immersed in 1\% sodium hypochlorite for $5 \mathrm{~min}$, rinsed five times in sterile water, and crushed with a sterilized glass rod. The resulting suspension was streaked on the Yeast Extract Mannitol Agar (YEMA), and the plates were then incubated at $28^{\circ} \mathrm{C}$ in dark for $72 \mathrm{~h}$. The isolated typical single colonies were re-streaked on freshly prepared YEMA plates to obtain pure cultures (Vincent, 1970). Single typical rhizobial colonies were sub-cultured on YEMA plates. Finally, a total of 24 rhizobial isolates were obtained, maintained, and preserved on YEMA supplemented with glycerol and kept at $-20^{\circ} \mathrm{C}$.

\section{Morphological characterization of the bacterial strains}

Rhizobial isolates were characterized morphologically by detecting different features such as color, colony size, motility, shape, and gram staining. Carbol fuchsin staining and motility test were conducted according to Crabtree and Hinsdill (1974).

\section{Biochemical characterization of the bacterial strains}

Samples of rhizobial isolates were subjected to different biochemical tests by using a standardized API $20 \mathrm{NE}$ and API 20E stripe kits (Biomerieux, France) according to the manufacturer's instructions (Niste et al., 2015), which included four groups of tests. The first group included enzyme utilization tests: $\beta$-galactopyranosidase, arginine dihydrolase (ADH), hydrogen sulfide $\left(\mathrm{H}_{2} \mathrm{~S}\right)$ production, tryptophan deaminase (TDA), lysine decarboxylase (LDC), ornithine decarboxylase (ODC), urease (URE), gelatinase (GLE), Voges Proskauer (VP), and citrate utilization (CIT). The second group included carbon source utilization tests: inositol, saccharose, melibiose, mannitol, rhamnose, glucose, sorbitol, amygdalin, and arabinose. The third group contained biochemical characterization tests: oxidase, esculin, potassium ni- 
trate, $\beta$-galactopyranoside, L-arginine, and tryptophan. The fourth group included utilization of different carbohydrate source tests: malate, caprate, mannose assimilation, N-acetyl-glucosamine, maltose, potassium gluconate, phenyl acetate, adipate, and trisodium citrate. A single well-isolated colony of each isolate (18-24 h old) was removed carefully and emulsified in $5 \mathrm{ml}$ of sterile saline to achieve a homogeneous bacterial suspension that was used immediately. The bacterial suspension was distributed into the tubes of the API $20 \mathrm{NE}$ and API $20 \mathrm{E}$ strips containing the dehydrated substrates carefully to avoid the formation of bubbles at the base of the tubes. Strips of API 20NE were incubated at $36 \pm 2{ }^{\circ} \mathrm{C}$ for $18-24 \mathrm{~h}$, and API $20 \mathrm{E}$ strips were incubated at $29^{\circ} \mathrm{C}$ for $24 \mathrm{~h}$. After the incubation period, the strips were read by referring to the reading table supplemented with the tests.

\section{Molecular characterization of the bacterial strains}

Genomic DNA was extracted from rhizobial isolates according to the method of Wilson (1997). The universal ribosomal 16S rRNA gene of bacteria was used for molecular characterization and phylogenetic studies as it is highly conserved between different species of bacteria. Primers $\mathrm{fD} 1$ and $\mathrm{rD} 1$ were used for the amplification of the 16S rRNA gene. fD1 (5' $5^{\prime}$ CCGAATTCGTCGACAAC AGAGTTTGATCCTGGCTCAG- $\left.3^{\prime}\right)$ and rD1 (5' - CCCG GGATCCAAGCTTAAGGAGGTGATCCAGCC- $3^{\prime}$ ) (Weisburg et al., 1991). The PCR reaction was performed in a $50 \mu \mathrm{l}$ reaction volume containing $100 \mathrm{ng}$ DNA, $25 \mu \mathrm{l}$ PCR Master Mix (2x My Taq ${ }^{\mathrm{TM}}$ Red Mix, Thermo Scientific Fisher, USA) and $20 \mu \mathrm{M}$ of forward and reverse primers. Amplifications were performed in the following conditions: initial denaturation at $95^{\circ} \mathrm{C}$ for $10 \mathrm{~min}, 35$ cycles at $95^{\circ} \mathrm{C}$ for $30 \mathrm{~s}, 58^{\circ} \mathrm{C}$ for $1 \mathrm{~min}, 72^{\circ} \mathrm{C}$ for $1 \mathrm{~min}$ and the final extension at $72^{\circ} \mathrm{C}$ for $10 \mathrm{~min}$. Aliquots $(5 \mu \mathrm{l})$ of the PCR products were separated on $1 \%(\mathrm{wt} / \mathrm{vol})$ agarose gels at $60 \mathrm{~V}$ for $1.5 \mathrm{~h}$ in $1 \mathrm{x}$ TBE buffer $(0.045 \mathrm{M}$ Tris-borate and $1 \mathrm{mM}$ EDTA, $\mathrm{pH} 8.2$ ), stained with ethidium bromide (final concentration $0.2 \mathrm{mg} / \mathrm{ml}$ ), and visualized by UVlight. The PCR products (amplified DNA) were purified, and the sequencing was performed by Macrogen Inc. (South Korea) using state-of-the-art robotics and instrumentation.

\section{Analyses of $16 S$ rRNA sequences}

The sequence analysis was conducted according to the method of Kumar and Ram (2018). The sequences of $16 \mathrm{~S}$ rRNA of the bacterial strains were compared with those of published bacterial type strains using the National Center for Biotechnology Information (NCBI) server. Sequence similarity searches were performed using BLASTN (http://www.ncbi.nlm.nih.gov/blast). The sequences from closely related strains as listed on the List of Prokaryotic names with Standing in Nomenclature (LPSN) (www.bacterio.net) and the reference strains were retrieved for phylogenetic analyses from the GenBank/EMBL database (http://www.ebi.ac.uk/ Tools/sss/fasta/nucleotide.html). For pairwise distance matrixes, multiple alignments were performed using the algorithm CLUSTAL Omega (https://www.ebi.ac.uk/ Tools/msa/clustalo/) provided by the European Bioinformatics Institute (EMBL-EBI).

\section{Accession numbers}

Sequences were submitted to GenBank through Bankit (a World Wide Web sequence submission server available at NCBI) and the accession numbers were given. The sequences are available online (http://www.ncbi. nlm.nih.gov) and can be located by the following accession numbers: MH733495, MH734103, MH734609, MH734109, MH733813, MH734608, MH734108, MH734182, MH734102, MH733593, MH735139, MH734620, MH734612, MH734185, MH734184, MH734195, MH734241, MH734242, and MH734613.

\section{Phylogenetic analyses}

For phylogenetic analyses, partial 16S rRNA gene sequences obtained in this study together with sequences retrieved from GenBank were aligned using the CLUSTAL W software in the MEGAX software package. A phylogenetic tree was constructed using the neighborjoining (NJ) and maximum likelihood (ML) methods in MEGA X software package. For ML analyses, the gene sequences were appropriately trimmed and subsequently concatenated. The best-fit models of nucleotide substitution were determined in MEGA X, and the most appropriate were selected for the construction of ML trees as referred in figure legends.

\section{Results and discussion}

A total of 24 isolates were obtained from surfacesterilized nodules of five legumes from seven Egyptian governorates; Menoufia, Gharbia, Suez, Dakahlia, Giza, 
Table 1. Morphological characterization of rhizobium isolates obtained from various legumes

\begin{tabular}{|c|c|c|c|c|c|c|c|}
\hline Isolate code & Host & Governorate & $\begin{array}{c}\text { Growth period } \\
\text { (days) } \\
\text { (fast/slow) }\end{array}$ & Colony morphology & $\begin{array}{c}\text { Cell } \\
\text { morphology }\end{array}$ & Motility & $\begin{array}{l}\text { Gram's } \\
\text { reaction }\end{array}$ \\
\hline MNF-EM-R1 & pea & Menofia & $2-3$ & small round, white & small rods & +ve & - ve \\
\hline MNF-EM-R7 & pea & Gharbia & $2-3$ & small round, white & small rods & $+\mathrm{ve}$ & $-\mathrm{ve}$ \\
\hline MNF-EM-R11 & pea & Suez & $2-3$ & small round, white & small rods & +ve & $-\mathrm{ve}$ \\
\hline MNF-EM-R12 & pea & Behyrah & $2-3$ & round, creamy & small rods & $+\mathrm{ve}$ & $-\mathrm{ve}$ \\
\hline MNF-EM-R500 & pea & Fayoum & $2-3$ & round, creamy & small rods & $+\mathrm{ve}$ & $-\mathrm{ve}$ \\
\hline MNF-EM-R501 & pea & Dakahlia & $2-3$ & round, creamy & small rods & +ve & $-\mathrm{ve}$ \\
\hline MNF-EM-R3 & faba bean & Menoufia & $2-3$ & round, watery & small rods & $+\mathrm{ve}$ & $-\mathrm{ve}$ \\
\hline MNF-EM-R4 & faba bean & Gharbia & $2-3$ & round, watery & small rods & $+\mathrm{ve}$ & $-\mathrm{ve}$ \\
\hline MNF-EM-R9 & faba bean & Suez & $2-3$ & round, watery & small rods & $+\mathrm{ve}$ & $-\mathrm{ve}$ \\
\hline MNF-EM-R15 & faba bean & Behyrah & $2-3$ & round, watery & small rods & $+\mathrm{ve}$ & $-\mathrm{ve}$ \\
\hline MNF-EM-R502 & faba bean & Giza & $2-3$ & round, watery & small rods & $+\mathrm{ve}$ & $-\mathrm{ve}$ \\
\hline MNF-EM-R503 & faba bean & Dakahlia & $2-3$ & round, creamy & small rods & $+\mathrm{ve}$ & $-\mathrm{ve}$ \\
\hline MNF-EM-R2 & clover & Gharbia & $2-3$ & small round, white & small rods & $+\mathrm{ve}$ & $-\mathrm{ve}$ \\
\hline MNF-EM-R504 & clover & Behyrah & $2-3$ & round, watery & small rods & $+\mathrm{ve}$ & $-\mathrm{ve}$ \\
\hline MNF-EM-R5 & clover & Suez & $2-3$ & round, creamy & small rods & $+\mathrm{ve}$ & $-\mathrm{ve}$ \\
\hline MNF-EM-R6 & clover & Menofia & $2-3$ & round, watery & small rods & $+\mathrm{ve}$ & $-\mathrm{ve}$ \\
\hline MNF-EM-R19 & clover & Menofia & $2-3$ & round, watery & small rods & $+\mathrm{ve}$ & $-\mathrm{ve}$ \\
\hline MNF-EM-R14 & lentil & Menofia & $2-3$ & round, creamy & small rods & $+\mathrm{ve}$ & $-\mathrm{ve}$ \\
\hline MNF-EM-R16 & lentil & Gharbia & $2-3$ & round, watery & small rods & $+\mathrm{ve}$ & $-\mathrm{ve}$ \\
\hline MNF-EM-R17 & lentil & Suez & $2-3$ & round, watery & small rods & $+\mathrm{ve}$ & $-\mathrm{ve}$ \\
\hline MNF-EM-R18 & lentil & Behyrah & $2-3$ & round, watery & small rods & $+\mathrm{ve}$ & $-\mathrm{ve}$ \\
\hline MNF-EM-R20 & soybean & Gharbia & $3-5$ & round, creamy & small rods & +ve & $-\mathrm{ve}$ \\
\hline MNF-EM-R21 & soybean & Suez & $3-5$ & round, creamy & small rods & $+\mathrm{ve}$ & $-\mathrm{ve}$ \\
\hline MNF-EM-R22 & soybean & Behyrah & $3-5$ & round, creamy & small rods & $+\mathrm{ve}$ & $-\mathrm{ve}$ \\
\hline
\end{tabular}

Fayoum, and Behyra. They were initially characterized using phenotypic traits, and they showed characteristics of Rhizobium spp. (Table 1). The colonies appeared white, watery, and creamy round, and the cells were small rods, motile, and gram-negative. These results are in agreement with the data previously published by ElZanaty et al. (2014) and Singh et al. (2018). Furthermore, the bacteria showed a growth period of 2-3 days for fast-growing bacteria (from faba bean, lentil, pea, and clover) and of 3-5 days for slow-growing bacteria (from soybean). These findings are in agreement with the classification of rhizobia into fast-growing Rhizobium and slow-growing Bradyrhizobium (Deshwal and Chaubey, 2014).
The commercially available API $20 \mathrm{NE}$ and API 20E biochemical identification system (bioMérieux) was used to identify the biochemical profiles of the isolates. The reactions were assigned according to the reading table provided by the manufacturer (Niste et al., 2015).

In enzyme activity profile tests, (data presented in Table 2), all isolates were positive for TDA. In contrast, they were unable to produce $\mathrm{H}_{2} \mathrm{~S}$. The obtained data showed that 15 isolates (62.5\%) produced ortho-nitrophenyl- $\beta$-galactosidase (ONPG). Nine isolates (37.5\%) showed color change (positive results) in the ADH test. Most isolates produced LDC, except for one MNF-EMR503 isolate from faba bean, one MNF-EM-R16 isolate from lentils, and two (MNF-EM-R20 and MNF-EM-R21) 
Table 2. Enzyme utilization of rhizobium isolates obtained from various legumes

\begin{tabular}{|c|c|c|c|c|c|c|c|c|c|c|}
\hline \multirow{2}{*}{ Isolate code } & \multicolumn{10}{|c|}{ API $20 \mathrm{E}$ tests } \\
\hline & ONPG & $\mathrm{ADH}$ & $\mathrm{H}_{2} \mathrm{~S}$ & TDA & $\mathrm{LDC}$ & ODC & URE & GLE & $\mathrm{VP}$ & CIT \\
\hline MNF-EM-R1 & + & + & - & + & - & - & + & - & + & + \\
\hline MNF-EM-R7 & - & - & - & + & - & + & + & - & + & + \\
\hline MNF-EM-R11 & + & + & - & + & - & - & + & - & + & + \\
\hline MNF-EM-R12 & - & - & - & + & - & - & - & - & + & + \\
\hline MNF-EM-R500 & + & + & - & + & - & + & - & - & + & + \\
\hline MNF-EM-R501 & + & - & - & + & - & - & + & - & + & + \\
\hline MNF-EM-R3 & - & + & - & + & - & - & - & + & - & - \\
\hline MNF-EM-R4 & + & + & - & + & - & - & + & - & + & - \\
\hline MNF-EM-R9 & - & - & - & + & - & - & - & - & + & - \\
\hline MNF-EM-R15 & - & - & - & + & - & - & + & + & + & - \\
\hline MNF-EM-R502 & - & - & - & + & - & - & - & - & + & - \\
\hline MNF-EM-R503 & + & - & - & + & + & - & - & + & - & + \\
\hline MNF-EM-R2 & + & + & - & + & - & + & + & + & + & - \\
\hline MNF-EM-R504 & - & - & - & + & - & - & + & - & + & + \\
\hline MNF-EM-R5 & + & - & - & + & - & - & - & - & + & - \\
\hline MNF-EM-R6 & + & - & - & + & - & - & + & - & + & - \\
\hline MNF-EM-R19 & - & - & - & + & - & - & - & - & + & + \\
\hline MNF-EM-R14 & - & + & - & + & - & - & - & + & + & + \\
\hline MNF-EM-R16 & + & - & - & + & + & - & - & - & + & + \\
\hline MNF-EM-R17 & + & + & - & + & - & - & - & + & + & + \\
\hline MNF-EM-R18 & + & - & - & + & - & - & - & + & + & + \\
\hline MNF-EM-R20 & + & + & - & + & + & - & + & + & + & + \\
\hline MNF-EM-R21 & + & + & - & + & + & + & + & + & + & + \\
\hline MNF-EM-R22 & + & + & - & + & - & - & + & + & + & - \\
\hline
\end{tabular}

ONPG - $\beta$-galactopyranosidase, ADH - arginine dihydrolase, $\mathrm{H}_{2} \mathrm{~S}-\mathrm{H}_{2} \mathrm{~S}$ production, TDA - tryptophan deaminase, LDC - lysine decarboxylase, ODC - ornithine decarboxylase, URE - urease, GLE - gelatinase, VP - voges proskauer, CIT - citrate utilization

isolates from soybean. Four isolates, including MNF-EMR20, showed positive results in the ODC test, while 12 (50\%) and $10(41.7 \%)$ isolates showed color change in urease (URE) and gelatinase (GLE) activity tests, respectively. All but two faba bean isolates (MNF-EM-R3 and MNF-EM-R503) were positive in the VP test. Bacterial isolates from pea and lentil were positive for the CIT test. Only one isolate (MNF-EM-R503) from faba bean and two isolates (MNF-EM-R504 and MNF-EMR19) from clover were positive in this test. These results showed some similarity to those previously reported by Niste et al. (2015), Patil et al. (2014), and
Shahzad et al. (2012). The results of the rhizobial isolates analyzed in this study agreed with these authors results for TDA and $\mathrm{H}_{2} \mathrm{~S}$ tests, although some variations were observed for other enzyme tests. These authors showed positive results for ONPG and URE and negative results for $\mathrm{ADH}, \mathrm{LDC}, \mathrm{ODC}, \mathrm{GLE}, \mathrm{VP}$, and CIT for the tested strains with no variations. The present study revealed that biochemical characteristics given in Table 2 for most of the isolates were quite similar to those of rhizobial strains. However, some isolates did not resemble standard rhizobial strains. These differences may be due to the differences in the ecological environments 
Table 3. Carbon source utilization by rhizobium isolates obtained from various legumes

\begin{tabular}{l|c|c|c|c|c|c|c|c|c}
\hline \multirow{2}{*}{ Isolate code } & \multicolumn{7}{|c}{ Carbon source } \\
\cline { 2 - 12 } & INO & SAC & MEL & MAN & RHA & GLU & SOR & AMY & ARA \\
\hline MNF-EM-R1 & - & - & - & - & - & - & - & - & - \\
\hline MNF-EM-R7 & + & - & + & + & + & + & + & + & - \\
\hline MNF-EM-R11 & + & + & + & + & + & + & + & + & + \\
\hline MNF-EM-R12 & - & - & - & + & - & + & - & - & - \\
\hline MNF-EM-R500 & + & + & + & + & + & + & + & + & + \\
\hline MNF-EM-R501 & - & + & + & - & + & + & - & - & + \\
\hline MNF-EM-R3 & + & + & + & + & + & + & + & + & + \\
\hline MNF-EM-R4 & - & - & - & - & - & - & - & - & - \\
\hline MNF-EM-R9 & - & - & - & + & - & + & - & - & - \\
\hline MNF-EM-R15 & + & + & + & + & + & + & + & + & + \\
\hline MNF-EM-R502 & + & + & + & + & + & + & + & - & + \\
\hline MNF-EM-R503 & + & + & - & + & + & - & + & - & + \\
\hline MNF-EM-R2 & + & + & + & + & + & + & + & + & + \\
\hline MNF-EM-R504 & - & - & - & + & - & + & - & - & + \\
\hline MNF-EM-R5 & - & - & - & + & - & - & - & - & - \\
\hline MNF-EM-R6 & + & - & - & + & - & - & - & - & - \\
\hline MNF-EM-R19 & - & - & - & + & - & + & - & - & - \\
\hline MNF-EM-R14 & + & - & + & + & + & - & + & - & + \\
\hline MNF-EM-R16 & + & + & + & + & + & + & + & + & + \\
\hline MNF-EM-R17 & - & + & + & + & + & - & - & + & + \\
\hline MNF-EM-R18 & - & - & - & + & - & - & - & - & - \\
\hline MNF-EM-R20 & + & + & - & - & + & + & - & - & - \\
\hline MNF-EM-R21 & + & + & + & + & + & + & + & + & + \\
\hline
\end{tabular}

INO - inositol, SAC - saccharose, MEL - melibiose, MAN - mannitol, RHA - rhamnose, GLU - glucose, SOR - sorbitol, AMY - amygdalin, ARA - arabinose

of the isolates. Hence, these isolates may not be considered as probable rhizobial isolates until further confirmation tests are conducted.

The results of API $20 \mathrm{E}$ tests for determining the ability to utilize different carbon sources are presented in Table 3. The data showed that MNF-EM-R1 and MNFEM-R4 were unable to use any of the tested sugars (negative) as the carbon source. One pea isolate (MNF-EMR501) and one soybean isolate (MNF-EM-R20) were unable to use mannitol as the carbon source. Thirteen rhizobial isolates (54.2\%) used inositol, saccharose, and melibiose. Eight isolates (33.3\%) did not utilize rhamnose. Glucose, sorbitol, and amygdalin were utilized by
$15(62.5 \%), 12(50 \%)$, and $10(41.7 \%)$ of the isolates, respectively. Finally, 14 (58.3\%) isolates assimilated arabinose. The tested isolates showed varied results for the utilization of different carbon sources, which is similar to the results reported by Rodrigues et al. (2018) for isolates obtained from the legume tree. This observed diversity is possibly due to their adaptation to different environments.

The results of other biochemical identification tests (Table 4) demonstrated that all the tested isolates could use oxidase and esculin, except for the isolates MNFEM-R22 and MNF-EM-R504. Seven isolates showed a negative reaction in the potassium nitrate test, in 
Table 4. Biochemical characterization of rhizobium isolates obtained from various legumes

\begin{tabular}{|c|c|c|c|c|c|c|}
\hline \multirow{2}{*}{ Isolate code } & \multicolumn{6}{|c|}{ Tests } \\
\hline & $\mathrm{OX}$ & ESC & $\mathrm{NO}_{3}$ & PNPG & $\mathrm{ADH}$ & TRP \\
\hline MNF-EM-R1 & + & + & - & + & + & - \\
\hline MNF-EM-R7 & + & + & - & + & - & - \\
\hline MNF-EM-R11 & + & + & - & + & + & - \\
\hline MNF-EM-R12 & + & + & + & + & - & - \\
\hline MNF-EM-R500 & + & + & + & + & + & - \\
\hline MNF-EM-R501 & + & + & + & + & - & - \\
\hline MNF-EM-R3 & + & + & + & + & + & + \\
\hline MNF-EM-R4 & + & + & - & + & - & - \\
\hline MNF-EM-R9 & + & + & - & + & - & - \\
\hline MNF-EM-R15 & + & + & - & + & - & - \\
\hline MNF-EM-R502 & + & + & - & + & - & - \\
\hline MNF-EM-R503 & + & + & - & + & - & - \\
\hline MNF-EM-R2 & + & + & + & + & + & - \\
\hline MNF-EM-R504 & + & - & - & + & - & - \\
\hline MNF-EM-R5 & + & + & - & + & - & - \\
\hline MNF-EM-R6 & + & + & - & + & - & - \\
\hline MNF-EM-R19 & + & + & - & + & - & - \\
\hline MNF-EM-R14 & + & + & - & - & + & - \\
\hline MNF-EM-R16 & + & + & - & + & - & + \\
\hline MNF-EM-R17 & + & + & + & - & + & - \\
\hline MNF-EM-R18 & + & + & - & + & - & - \\
\hline MNF-EM-R20 & + & + & + & + & + & - \\
\hline MNF-EM-R21 & + & + & - & + & + & + \\
\hline MNF-EM-R22 & - & + & - & + & - & - \\
\hline
\end{tabular}

$\mathrm{OX}$ - oxidase, ESC - esculin, $\mathrm{NO}_{3}$ - potassium nitrate, $\mathrm{PNPG}$ - $\beta$-galactopyranoside, ADH - l-arginine, TRP - tryptophan

which where the rhizobial isolates were unable to reduce nitrates to nitrites, and thus, no red color developed in the culture medium. All the tested isolates were positive for $\beta$-galactopyranoside assimilation, except for two isolates (MNF-EM-R4 and MNF-EM-R17) that were isolated from lentil plants. Over half of the isolates showed inability to assimilate L-arginine and tryptophan $(62.5 \%$ and $87.5 \%$, respectively). The obtained results agreed with those of Shoukry et al. (2013) who tested rhizobial isolates from the nodules of Faba bean plants.

Moreover, the ability of the isolates to assimilate 10 carbohydrate sources was tested. The results presented in Table 5 indicate that six isolates (25\%) showed a positive response for the utilization of malate and caprate as the carbohydrate source. In contrast, five isolates (20.8\%) showed negative results for mannose and N-acetyl-glucosamine, and only seven isolates (29.2\%) could assimilate maltose and potassium gluconate. Ten isolates (41.7\%) could utilize phenyl acetate, and only four isolates (16.7\%) could use adipate. Several authors such as Graham and Parker (1964), Hussain et al. (2002), RamírezBahena et al. (2008), and Dekak et al. (2018) have shown vast differences in the ability of rhizobia to utilize various carbohydrate sources. 
Table 5. Utilization of different carbohydrate sources by rhizobium isolates obtained from various legumes

\begin{tabular}{l|c|c|c|c|c|c|c|c}
\hline \multirow{2}{*}{ Isolate code } & \multicolumn{7}{|c}{ Carbohydrate } \\
\cline { 2 - 11 } & MLT & CAP & MNE & NAG & MAL & GNT & PAC & ADI \\
\hline MNF-EM-R1 & + & - & + & + & + & + & - & - \\
\hline MNF-EM-R7 & + & - & + & + & + & + & - & - \\
\hline MNF-EM-R11 & + & - & + & + & + & + & + & - \\
\hline MNF-EM-R12 & - & - & + & + & + & - & - & - \\
\hline MNF-EM-R500 & + & - & + & + & + & + & + & - \\
\hline MNF-EM-R501 & - & - & + & + & + & - & - & - \\
\hline MNF-EM-R3 & + & + & + & + & + & + & + & - \\
\hline MNF-EM-R4 & + & + & + & + & + & + & - & - \\
\hline MNF-EM-R9 & - & - & - & - & - & - & - & - \\
\hline MNF-EM-R15 & + & - & + & + & + & + & - & - \\
\hline MNF-EM-R502 & + & - & - & + & - & + & + & + \\
\hline MNF-EM-R503 & + & + & + & + & + & + & + & + \\
\hline MNF-EM-R2 & + & - & + & + & + & + & + & - \\
\hline MNF-EM-R504 & - & - & - & - & - & + & - & - \\
\hline MNF-EM-R5 & - & - & - & - & - & - & - & - \\
\hline MNF-EM-R6 & - & - & - & - & - & - & - & - \\
\hline MNF-EM-R19 & + & - & - & - & - & - & - & - \\
\hline MNF-EM-R14 & + & + & + & + & - & + & - & + \\
\hline MNF-EM-R16 & + & - & + & + & + & + & + & + \\
\hline MNF-EM-R17 & + & + & + & + & + & + & - & - \\
\hline MNF-EM-R18 & + & - & + & + & + & + & + & + \\
\hline MNF-EM-R20 & + & - & + & + & + & + & + & - \\
\hline MNF-EM-R21 & + & + & + & + & + & + & + & + \\
\hline
\end{tabular}

MLT - malate, CAP - caprate, MNE - mannose assimilation, NAG - N-acetyl-glucosamine, MAL - maltose, GNT - potassium gluconate, PAC - phenyl acetate, ADI - adipate, CIT - trisodium citrate

Biochemical profiling of rhizobia by using the API strips is widely applied in studies of species description (Delamuta et al., 2015; Shamseldin et al., 2016). This is a rapid and easy test that reveals several biochemical characteristics of plant-associated bacteria and has been applied to characterize rhizobial collections (Dias et al., 2013; Niste et al., 2015; Rodrigues et al., 2018). The results of these biochemical tests reveal a large diversity among the isolates investigated in the present study, which may be due to their adaptation in different environments or due to their functional diversity (Gilbert et al., 2010; Miki et al., 2014). Although these results indicate the importance of biochemical characteristics to better understand functional diversity, they are also complementary to DNA taxonomic assessments (Rodrigues et al., 2018).

Molecular characterization and phylogenetic analysis were conducted using genomic DNA of all isolates. PCR amplification of the 16S rRNA gene of all isolates resulted in the amplification of $1300 \mathrm{bp}$ DNA fragments. PCR products were sequenced, and the BLAST program was used to determine the species identity of isolates (Table 6). By comparing the sequences of the 16S rRNA gene to those deposited in GenBank, $79.2 \%$ of the isola- 
Table 6. Molecular identification of rhizobium isolates obtained from various legumes by NCBI BLAST N

\begin{tabular}{|c|c|c|c|c|c|}
\hline Isolate code & Alignment description & E-value & $\begin{array}{c}\text { Max } \\
\text { identification } \\
{[\%]}\end{array}$ & $\begin{array}{l}\text { Accession } \\
\text { number }\end{array}$ & Species name \\
\hline MNF-EM-R1 & $\begin{array}{l}\text { KJ634558.1 } \\
\text { Rhizobium leguminosarum bv. viciae strain SWD43 }\end{array}$ & 0.0 & 95.69 & MH733495 & $\begin{array}{l}\text { Rhizobium } \\
\text { leguminosarum }\end{array}$ \\
\hline MNF-EM-R7 & $\begin{array}{l}\text { MG274266.1 } \\
\text { Rhizobium leguminosarum strain ALD2.7 }\end{array}$ & 0.0 & 92.73 & MH734103 & $\begin{array}{l}\text { Rhizobium } \\
\text { leguminosarum }\end{array}$ \\
\hline MNF-EM-R11 & $\begin{array}{l}\text { MG274266.1 } \\
\text { Rhizobium leguminosarum strain ALD2.7 }\end{array}$ & 0.0 & 90.87 & MH734609 & $\begin{array}{l}\text { Rhizobium } \\
\text { leguminosarum }\end{array}$ \\
\hline MNF-EM-R12 & $\begin{array}{l}\text { KY940047.1 } \\
\text { Rhizobium leguminosarum strain RP1 }\end{array}$ & 0.0 & 95.33 & MH734109 & $\begin{array}{l}\text { Rhizobium } \\
\text { leguminosarum }\end{array}$ \\
\hline MNF-EM-R3 & $\begin{array}{l}\text { AB971246.1 } \\
\text { Rhizobium leguminosarum gene clone NGB-CR-18 }\end{array}$ & 0.0 & 81.74 & MH733813 & $\begin{array}{l}\text { Rhizobium } \\
\text { leguminosarum }\end{array}$ \\
\hline MNF-EM-R4 & $\begin{array}{l}\text { MG274266.1 } \\
\text { Rhizobium leguminosarum strain ALD2.7 }\end{array}$ & 0.0 & 92.56 & MH734608 & $\begin{array}{l}\text { Rhizobium } \\
\text { leguminosarum }\end{array}$ \\
\hline MNF-EM-R9 & $\begin{array}{l}\text { KF670819.1 } \\
\text { Rhizobium leguminosarum bv. viciae strain ASU }\end{array}$ & 0.0 & 88.01 & MH734108 & $\begin{array}{l}\text { Rhizobium } \\
\text { leguminosarum }\end{array}$ \\
\hline MNF-EM-R15 & $\begin{array}{l}\text { KY940047.1 } \\
\text { Rhizobium leguminosarum strain RP1 }\end{array}$ & 0.0 & 97.55 & MH734182 & $\begin{array}{l}\text { Rhizobium } \\
\text { leguminosarum }\end{array}$ \\
\hline MNF-EM-R6 & $\begin{array}{l}\text { KY940047.1 } \\
\text { Rhizobium leguminosarum strain RP1 }\end{array}$ & 0.0 & 96.91 & MH734102 & $\begin{array}{l}\text { Rhizobium } \\
\text { leguminosarum }\end{array}$ \\
\hline MNF-EM-R2 & $\begin{array}{l}\text { MG230195.1 } \\
\text { Rhizobium leguminosarum strain RPN1 }\end{array}$ & 0.0 & 96.14 & MH733593 & $\begin{array}{l}\text { Rhizobium } \\
\text { leguminosarum }\end{array}$ \\
\hline MNF-EM-R5 & $\begin{array}{l}\text { KJ634558.1 } \\
\text { Rhizobium leguminosarum bv. viciae strain SWD43 }\end{array}$ & 0.0 & 95.69 & MH735139 & $\begin{array}{l}\text { Rhizobium } \\
\text { leguminosarum }\end{array}$ \\
\hline MNF-EM-19 & $\begin{array}{l}\text { KY495212.1 } \\
\text { Rhizobium leguminosarum strain CGAPGPBRS-025 }\end{array}$ & 0.0 & 98.69 & MH734620 & $\begin{array}{l}\text { Rhizobium } \\
\text { leguminosarum }\end{array}$ \\
\hline MNF-EM-R14 & $\begin{array}{l}\text { MG230195.1 } \\
\text { Rhizobium leguminosarum strain RPN1 }\end{array}$ & 0.0 & 95.23 & MH734612 & $\begin{array}{l}\text { Rhizobium } \\
\text { leguminosarum }\end{array}$ \\
\hline MNF-EM-R16 & $\begin{array}{l}\text { MG230195.1 } \\
\text { Rhizobium leguminosarum strain RPN }\end{array}$ & 0.0 & 93.31 & MH734185 & $\begin{array}{l}\text { Rhizobium } \\
\text { leguminosarum }\end{array}$ \\
\hline MNF-EM-R17 & $\begin{array}{l}\text { MG274266.1 } \\
\text { Rhizobium leguminosarum strain ALD2.7 }\end{array}$ & 0.0 & 94.94 & MH734184 & $\begin{array}{l}\text { Rhizobium } \\
\text { leguminosarum }\end{array}$ \\
\hline MNF-EM-R18 & $\begin{array}{l}\text { MF996753.1 } \\
\text { Rhizobium leguminosarum strain LRM-5 }\end{array}$ & 0.0 & 97.31 & MH734195 & $\begin{array}{l}\text { Rhizobium } \\
\text { leguminosarum }\end{array}$ \\
\hline MNF-EM-R20 & MH688810.1 & 0.0 & 83.86 & MH734241 & $\begin{array}{l}\text { Bradyrhizobium } \\
\text { japonicum }\end{array}$ \\
\hline MNF-EM-R21 & $\begin{array}{l}\text { KY940048.1 } \\
\text { Bradyrhizobium japonicum strain RV9 }\end{array}$ & 0.0 & 99.21 & MH734242 & $\begin{array}{l}\text { Bradyrhizobium } \\
\text { japonicum }\end{array}$ \\
\hline MNF-EM-R22 & $\begin{array}{l}\text { MH688810.1 } \\
\text { Bradyrhizobium sp. strain B918 }\end{array}$ & 0.0 & 83.33 & MH734613 & $\begin{array}{l}\text { Bradyrhizobium } \\
\text { japonicum }\end{array}$ \\
\hline
\end{tabular}

tes were identified to the species level with homology percentages ranging between $81.74 \%$ and $98.69 \%$ (Table 6). According to the results, the isolates from pea, faba bean, clover, and lentil were Rhizobium leguminosarum, while the isolates from soybean were Bradyrhizobium japonicum. However, MNF-EM-R500, MNF-
EM-R501, MNF-EM-R502, MNF-EM-R503, and MNFEM-R504 were characterized only as rhizobia. These data are consistent with previous reports. Zahran et al. (2013) conducted the sequences analysis of 16S rRNA and indicated that the strains from $V$. faba grown in the cultivated lands of Beni-Suef Governorate had 99.6\% 
Table 7. Nucleotide frequencies of the $16 \mathrm{~S}$ rRNA region sequences for rhizobium isolates obtained from various legumes

\begin{tabular}{l|c|c|c|c|c|c}
\hline \multicolumn{1}{c|}{ Isolate code } & $\begin{array}{c}\mathrm{T} \\
{[\%]}\end{array}$ & $\begin{array}{c}\mathrm{C} \\
{[\%]}\end{array}$ & $\begin{array}{c}\mathrm{A} \\
{[\%]}\end{array}$ & $\begin{array}{c}\mathrm{G} \\
{[\%]}\end{array}$ & $\begin{array}{c}\mathrm{G}+\mathrm{C} \\
{[\%]}\end{array}$ & $\begin{array}{c}\text { Length(nt) analyzed } \\
\text { data set }\end{array}$ \\
\hline MNF-EM-R1 & 21.4 & 21.5 & 25.5 & 31.5 & 53 & $855 \mathrm{bp}$ \\
\hline MNF-EM-R7 & 19.1 & 23.0 & 24.9 & 33.0 & 56 & $922 \mathrm{bp}$ \\
\hline MNF-EM-R11 & 19.7 & 23.4 & 24.5 & 32.5 & 55.9 & $985 \mathrm{bp}$ \\
\hline MNF-EM-R12 & 19.7 & 23.4 & 25.3 & 31.6 & 55 & $998 \mathrm{bp}$ \\
\hline MNF-EM-R3 & 22.0 & 22.0 & 27.2 & 28.7 & 50 & $540 \mathrm{bp}$ \\
\hline MNF-EM-R4 & 19.3 & 24.2 & 24.6 & 31.9 & 56.1 & $966 \mathrm{bp}$ \\
\hline MNF-EM-R9 & 24.6 & 23.1 & 25.4 & 26.9 & 50 & $778 \mathrm{bp}$ \\
\hline MNF-EM-R15 & 20.7 & 22.3 & 24.6 & 32.4 & 54.7 & $618 \mathrm{bp}$ \\
\hline MNF-EM-R6 & 20.3 & 22.9 & 25.7 & 31.2 & 54.1 & $651 \mathrm{bp}$ \\
\hline MNF-EM-R2 & 19.7 & 22.9 & 25.7 & 31.7 & 54.6 & $993 \mathrm{bp}$ \\
\hline MNF-EM-5 & 20.6 & 23.6 & 23.9 & 32.0 & 55.6 & $870 \mathrm{bp}$ \\
\hline MNF-EM-R504 & 19.3 & 24.2 & 24.6 & 31.9 & 56.1 & $966 \mathrm{bp}$ \\
\hline MNF-EM-R14 & 18.8 & 23.4 & 25.4 & 32.4 & 55.8 & $964 \mathrm{bp}$ \\
\hline MNF-EM-R16 & 19.6 & 23.3 & 25.1 & 32.0 & 55.3 & $806 \mathrm{bp}$ \\
\hline MNF-EM-R17 & 21.0 & 22.9 & 24.8 & 31.3 & 54.2 & $1411 \mathrm{bp}$ \\
\hline MNF-EM-R18 & 21.4 & 21.6 & 26.0 & 31.0 & 52.6 & $813 \mathrm{bp}$ \\
\hline MNF-EM-19 & 20.4 & 22.1 & 25.5 & 32.0 & 54.1 & $986 \mathrm{bp}$ \\
\hline MNF-EM-R20 & 19.8 & 21.6 & 25.8 & 32.8 & 54.4 & $980 \mathrm{bp}$ \\
\hline MNF-EM-R21 & 19.7 & 22.5 & 25.1 & 32.6 & 55.1 & $1003 \mathrm{bp}$ \\
\hline MNF-EM-R22 & 20.3 & 23.4 & 25.2 & 31.1 & 54.5 & $974 \mathrm{bp}$ \\
\hline
\end{tabular}

identity with $R$. leguminosarum. Ismail et al. (2013) also indicated that rhizobium isolated from the root nodules of broad beans ( $V$. faba L.) growing in 10 locations in Egypt were $R$. leguminosarum, and they found a narrow genetic distance among isolates. Fahmi et al. (2011), Hassan et al. (2015), and Ismael et al. (2018) supported the same results on $V$. faba. The narrow genetic variations could also possibly be due to the conserved nature of the 16S rRNA gene, which could not discriminate between closely related rhizobia species (Berrada et al., 2012). In addition, horizontal gene transfer and genetic recombination could have possibly contributed to the limited genetic variation of rhizobia in Egypt.

The 16S rRNA assay demonstrated the presence of two species of rhizobia, namely $R$. leguminosarum and $B$. japonicum, supporting the idea that there is a narrow diversity of species of this genus in Egypt. According to these data, the largest number of isolates (16 isolates) were classified as $R$. leguminosarum, suggesting that this strain predominates in the four legumes: faba bean ( $V$. faba), clover ( $T$. alexandrinum), pea ( $P$. sativum), and lentil ( $L$. culinaris) in the seven governorates of Egypt under study. In conclusion, these findings demonstrated that the rhizobial isolates in the present study are closely related and may have a recent common ancestral origin (Hassan et al., 2015). This may also be due to a high degree of conservation of the $16 \mathrm{~S}$ rRNA molecule (Berrada et al., 2012). The horizontal gene transfer and genetic recombination could also have possibly contributed to the limited genetic variation of rhizobia in the investigated governorates.

Comparison of the small subunit of the ribosomal RNA (SSU rRNA) has become the standard method for assessing phylogenetic relationships among bacteria (Olsen et al., 1994). The 16S rRNA gene-based phylogenetic tree was constructed and showed that the analyzed 19 microsymbionts clustered in a well-resolved phylogram (Fig. 1). In the phylogram of 16S-rRNA gene 


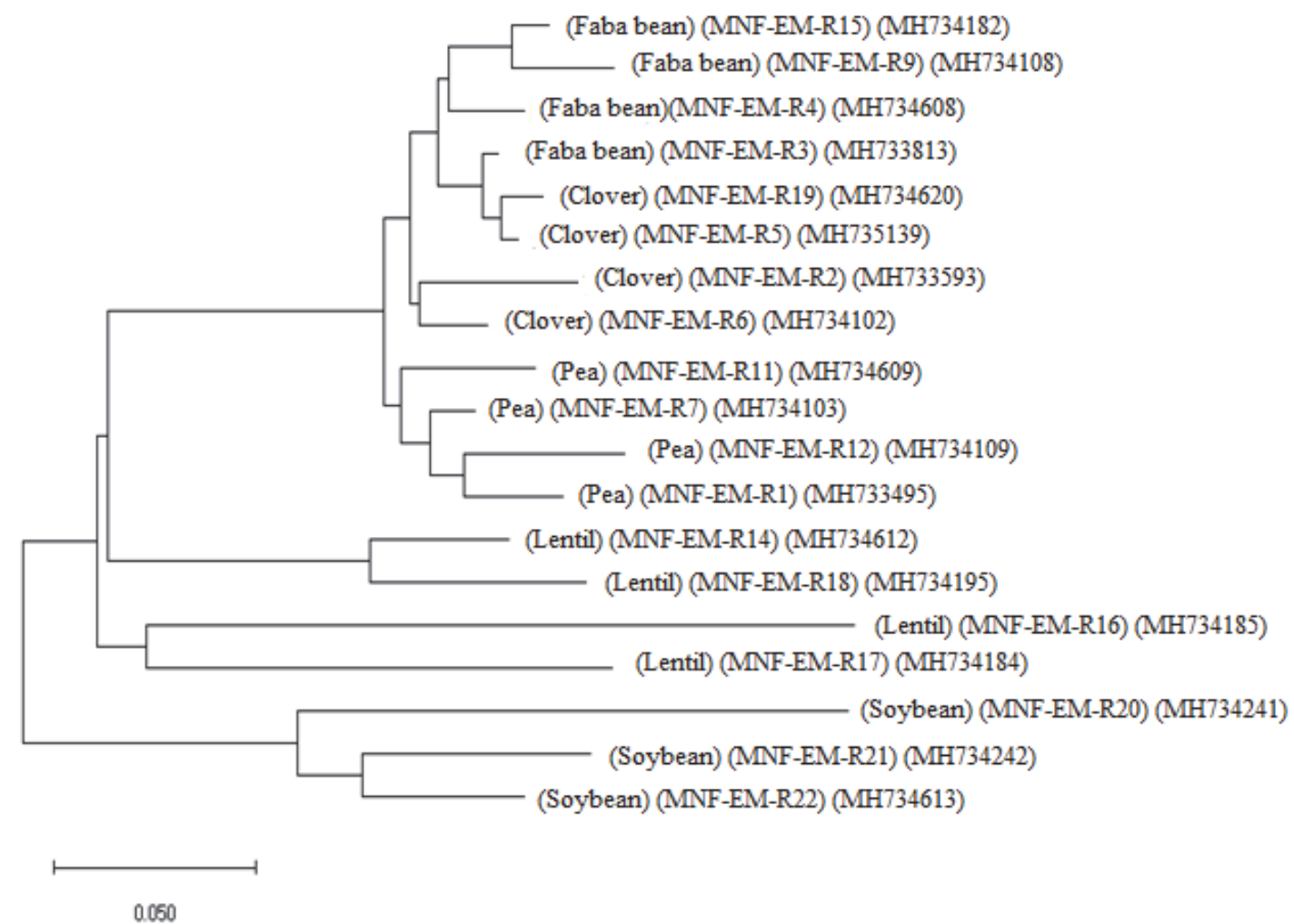

Fig. 1. A phylogenetic tree based on $16 \mathrm{~S}$ rRNA gene sequences amplified from pea, faba bean, clover, lentil, and soybean for the genera Rhizobium and Bradyrhizobium. The tree was constructed using the neighborjoining (NJ) and maximum likelihood (ML) method. GenBank accession numbers are given in parentheses. Numbers at nodes indicate the levels of bootstrap support based on the neighbor-joining analysis of 1000 resampled datasets. Bootstrap values below $40 \%$ are not shown. The isolates from pea, faba bean, clover, and lentil were Rhizobium leguminosarum, and the isolates from soybean were Bradyrhizobium japonicum

sequences, the $B$. japonicum isolates formed a separate cluster. They were phylogenetically divergent from all other $R$. leguminosarum rhizobia included in the analysis and formed an independent branch in the phylogram. The 16S rRNA tree also revealed that all $R$. leguminosarum isolates were in one cluster, which indicates the possibility that this gene originated from a common ancestor. Furthermore, each group of isolates originating from the root nodule of a particular legume formed a separate subcluster. The following groups of isolates, namely MNF-EM-R3, MNF-EM-R4, MNF-EM-R9, and MNF-EM-R15 from faba bean; MNF-EM-R2, MNF-EMR5, MNF-EM-R6, and MNF-EM-R19 from clover; MNFEM-R1, MNF-EM-R7, MNF-EM-R11, and MNF-EM-R12 from pea; and MNF-EM-R14, MNF-EM-R17, MNF-EMR18, and MNF-EM-R19 from lentil, were very close to each other in the phenogram. These data confirmed the distinctness of the classical slow-growers, the genus Bradyrhizobium, and showed that the fast-growers are rather diverse. These results also confirmed the wellestablished information that the species $R$. leguminosarum has three biovars: biovar viciae nodulates the tribe Vicieae, biovar trifolii nodulates Trifolium, and biovar phaseoli nodulates Phaseolus (Jordan, 1984). These biovars could not be reliably differentiated from each other, except by their host range. Therefore, the phylogram (Fig. 1) showed that $R$. leguminosarum of faba bean (probably biovar viciae) was separate in a subcluster and was the most divergent among the slowgrowing Bradyrhizobium. The three other $R$. leguminosarum isolates (most probably biovar trifolii) formed three subclusters, and each one belonged to a specific plant host.

The distribution of nucleotides and the guanosine and cytosine $(\mathrm{G}+\mathrm{C})$ content in the $16 \mathrm{~S}$ rRNA sequences of the 19 isolates are given in Table 6 . The length of the sequences analyzed varied from 540 to $1411 \mathrm{bp}$ in all the tested accessions, and the GC content ranged from 52.6 
to $56.1 \%$. The results showed that $16 \mathrm{~S}$ rRNA gene sequences were very conservative. Although they varied in lengths, there was very limited genetic differentiation among different isolates. Consequently, there was no variation among individuals of the same species. This indicated a narrow range of interspecies variations, which is consistent with the belief that biovars are present among the species.

\section{Conclusions}

Biofertilizer production is important because of the high cost of nitrogen-based chemical fertilizers. Therefore, the knowledge of genetic variations among native rhizobia could aid in selecting novel rhizobial strains that could be developed and used as biofertilizers. In the present study, 24 rhizobial isolates from five legumes that originated from Egypt were characterized, and their phylogenetic relationships were determined. Phenotypically, the isolates were characterized as rhizobia and were classified into the fast-growing Rhizobium and slow-growing Bradyrhizobium. Biochemical profiling showed a large diversity among the isolates, which may be mainly due to their functional diversity. By comparing the sequences of the 16S rRNA genes, the isolates were identified to the species level, and a high level of homology was observed among them. This limited genetic variation might be due to the high degree of conservation of the $16 \mathrm{~S}$ rRNA molecule and the horizontal gene transfer among rhizobia.

\section{Acknowledgments}

The authors are very grateful to Menoufia University for funding this project (Project name: The use of biotechnology in the biological treatment of agricultural waste and the production of bio-fertilizers.)

\section{References}

Batista L., Irisarri, P., Rebuffo M., Cuitińo J., Sanjuán Monza J. (2015) Nodulation competitiveness as a requisite for improved rhizobial inoculants of Trifolium pratense. Biol. Fertil. Soils 51: 11-20.

Berrada H., Noxious I., Houssaini M., Ghachtouli N., Gtari M., Benbrahim K. (2012) Phenotypic and genotypic characterizations of rhizobia isolated from root nodules of multiple legume species natives of Fez, Morocco. Afr. J. Microbiol. Res. 6: 5314-5324.

Casamatta D.A., Johansen J.R., Vis M.L., Broadwater S.T. (2005) Molecular and morphological characterization of ten polar and near-polar strains within the Oscillatoriales (Cyanobacteria). J. Phycol. 41: 421-438.
Chaintreuil C., Girayd I.E., Prin Y., Lorquin J., Monique G., Lajudie P., Dreyfus B. (2000) Photosynthetic Bradyrhizobia are natural Endophytes of the African wild rice Oryza breviligulata. Appl. Environ. Microbiol. 66 (12): 5437-5447.

Crabtree T., Hinsdill D. (1974) [in:] Fundamental experiments in microbiology. $4^{\text {th }}$ edition. W.B. Saunders Company, West Washington Square, Philadelphia, USA: 27-30.

Dekak A. Chabi R., Menasria T., Behizia Y. (2018) Phenotypic characterization of rhizobia nodulating legumes Genista microcephala and Argyrolobium uniflorum growing under arid conditions. J. Adv. Res. 14: 35-42.

Delamuta J., Ribeiro R., Ormeño-Orrillo E., Parma M., Melo I., Martínez-Romero E., Hungria M. (2015) Bradyrhizobium tropiciagri sp. nov. and Bradyrhizobium embraces sp. nov., nitrogen-fixing symbionts of tropical forage legumes. Int. J. Sys. Evol. Microbiol. 65: 4424-4433.

Deshwal V.K., Chaubey A. (2014) Isolation and characterization of Rhizobium leguminosarum from root nodule of Pisum sativum L. J. Artif. Int. Res. 2(8): 464-467.

Dias A., dos Santos G.S., Vasconcelos V.G., Radl V., Xavier G.R., Rumjanek N.G., Ribeiro R.D.D. (2013) Screening of plant growth-promoting rhizobacteria for the development of vegetable crops inoculants. Afr. J. Microbiol. Res. 7(19): 2087-2092.

Eissa R.A., Abd-El-Bary M.E., Fahmi A.I., Nagaty H.H., Hassan M.M. (2009) Evaluation and characterization of $\gamma$ induced mutants of Rhizobium leguminosarum in Vicia faba. [in:] Pro-

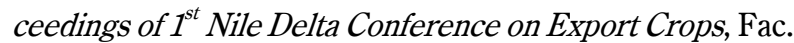
of Agric., Minufiya Univ., Shebin El-Kom, Egypt: 157-170.

El-Zanaty A.M., Abdel-lateif K., Elsobky M. (2014) Molecular identification of Rhizobium isolates nodulating Faba bean plants in Egyptian soils. J. Bioprocess Biotech. 5: 1-4.

Fahmi A.I., Nagaty H.H., Eissa R.A., Hassan M.M. (2011) Effects of salt stress on some nitrogen fixation parameters in faba bean. Pakis. J. Biol. Sci. 14 (6): 285-291.

Gilbert J., Field D., Swift P., Simon T., Cummings D., Temperton B., Weynberg K., Huse S., Hughes M., Joint I., Somerfield P., Muhling M. (2010) The taxonomic and functional diversity of microbes at a temperate coastal site: a 'MultiOmic' study of seasonal and diel temporal variation. PLoS ONE 5(11): e15545.

Graham P.H., Parker C.A. (1964) Diagnostic features in the characterization of root-nodule bacteria of legumes. Plant Soil 20(3): 383-396.

Hassan M.M., Fahmi A.I., Eissa R.A., Nagaty H.H. (2015) Diversity of Rhizobia nodulating faba bean (Vicia faba) growing in Egypt. J. Microb. Biochem. Technol. 7(3): 152-159.

Hussain N., Mujeeb F., Tahir M., Khan G.D., Hassan N.M., Bari A. (2002) Effectiveness of rhizobium under salinity stress. Asian J. Plant Sci. 1: 12-14.

Ismael R., Omar N., Azzam C., Ahmad E., Abdel-Fattah M., Zahran H. (2018) Characterization and evaluation of Rhizobium isolates from Vicia faba for some plant growth-promoting traits. Biosci. Res. 15(4): 2971-2982.

Ismail M., El-Zanaty A.M., Eissa R.A., Hewedy O. (2013) Genetic diversity of Rhizobium leguminosarum as revealed by 
$16 S$ rRNA gene sequence. Am.-Euras. J. Agric. Environ. Sci. 13(6): 797-801.

Jordan D.C. (1984) Family III Rhizobiaceae. [in:] Bergey's manual of systematic bacteriology. Ed. Kreig N.R., Holt J.G. Williams and Wilker, Baltimore: 234- 242.

Kiers E.T., West S.A., Denison R.F. (2002) Mediating mutualisms: farm management practices and evolutionary changes in symbiont co-operation. J. Appl. Ecol. 39: 745-754.

Kumar G.K., Ram M.R. (2018) Preliminary characterization of Rhizobacterial strains isolated from legume [Vigna trilobata (L.) verdc.] Root Nodules. Int. J. Sci. Res. Technol. 7(4): 279-284.

Litvaitis M. (2002) A molecular test of cyanobacterial phylogeny: inferences from constraint analyses. Hydrobiologia 468(1-3): 135-145.

Miki T., Yokokawa T., Matsui K. (2014) Biodiversity and multifunctionality in a microbial community: a novel theoretical approach to quantify functional redundancy. Proc. R. Soc. B https://doi.org/10.1098/rspb.2013.2498

Mus F., Crook M., Garcia K., Costas G., Geddes B., Kouri E., Paramasivan P., Ryu M., Oldroyd G., Poole P., Udvardi M., Voigt C., Ané J., Peters J. (2016) Symbiotic nitrogen fixation and challenges to extending it to non-legumes. Appl. Environ. Microbiol. 82(13): 1-16.

Ngakou A., Megueni C., Ousseni H., Massai A. (2009) Study on the isolation and characterization of rhizobia strains as biofertilizer tools for growth improvement of four-grain legumes in Ngaoundéré-Cameroon. Int. J. Biol. Chem. Sci. 3(5): 1078-1089.

Niste M., Vidican R., Puia C., Rotar I., Pop R. (2015) Isolation and biochemical characterization of Rhizobium leguminosarum bv. trifolii and Sinorhizobium meliloti using API 20 NE and API 20 E. Bull. UASVM Agric. 72(1): 173-178.

Olsen G., Matsuda H., Hagstrom R., Overbeek R. (1994) FastDNAmL: a tool for construction of phylogenetic trees of DNA sequences using maximum likelihood. Comput. Appl. Biosci. 10(1): 8-41.

Rajaniemi P., Hrouzek P., Kastovska K., Willame R., Rantala A., Hoffmann L., Komárek J., Sivonen K. (2005) Phylogenetic and morphological evaluation of the genera Anabaena, Aphanizomenon, Trichormus and Nostoc (Nostocales, Cyanobacteria). Int. J. Syst. Evol. Microbiol. 55(1): 11-26.

Ramírez-Bahena M.H., García-Fraile P., Peix A., Valverde A., Rivas R., Igual J.M., Mateos P.F., Martínez-Molina E., Velázquez E. (2008) Revision of the taxonomic status of the speciesRhizobiumleguminosarum (Frank 1879) Frank 1889AL, Rhizobium phaseoli Dangeard 1926AL and Rhizobium trifolii Dangeard 1926AL. $R$. trifolii is a later synonym of $R$. legu- minosarum. Reclassification of the strain $R$. leguminosarum DSM 30132 (NCIMB 11478) as Rhizobium pisi sp. nov. Int. J. Syst. Evol. Microbiol. 58(11): 2484-2490.

Rodrigues D., Aleksandro D., Cavalcantia M., Escobard I., Fraizd A., Ribeirof P., Netoe R., Freitas A., Fernandes-Júniorg P. (2018) Phenotypic, genetic and symbiotic characterization of Erythrina velutina rhizobia from Caatinga dry forest. Braz. J. Microbiol. 49: 503-512.

Shahzad F., Shafee M., Abbas F., Babar S.M., Tariq M., Ah$\operatorname{mad} Z$. (2012) Isolation and biochemical characterization of Rhizobium meliloti from root nodules of Alfalfa (Medicago Sativa). J. Anim. Plant Sci. 22(2): 522-524.

Shamseldin A., Carro L., Peix L., Velázquez E., Moawad H., Sadowsky M. (2016) The symbiovar Trifolii of Rhizobium bangladeshense and Rhizobium aegyptiacum sp. nov. nodulate Trifolium alexandrinum in Egypt. Syst. Appl. Microbiol. 4(39): 275-279.

Shoukry A.A., Khattab A.A., Abou-Ellail M., El-Shabrawy H. (2013) Molecular and biochemical characterization of new Rhizobium leguminosarum bio viciae strains isolated from different locations of Egypt. J. Appl. Sci. Res. 9(11): 5864-5877.

Singh K., Gera R., Kumar R. (2018) Isolation and characterization of siderophore producing rhizobia from Sesbania sesban using different types of Indian soils. Int. J. Chem. Stud. 6(3): 797-800

Svenning J., Wright J. (2005) Seed limitation in a Panamanian forest. J. Ecol. 93: 853-862

Vincent J.M. (1970) [in:] A manual for the practical study of root nodule bacteria. IBP Handbook No. 15. Brockwell. Oxford.

Weisburg W., Barns S., Pelletier D., Lane D. (1991) 16S ribosomal DNA amplification for phylogenetic study. J. Bacteriol. 173(2): 697-703.

Wilson K. (1997) Preparation of genomic DNA from bacteria. [in:] Current protocols in molecular biology. Ed. Ausubel F.M., Brent R., Kingston R.E., Moore D.D., Seidman J.G., Smith J.A., Struhl K. Wiley \& Sons, New York: 2.4.1-2.4.5.

Yadav J., Verma J. (2014) Effect of seed inoculation with indigenous Rhizobium and plant growth-promoting rhizobacteria on nutrients uptake and yields of chickpea (Cicer arietinum L.). Eur. J. Soil. Biol. 63: 70-77.

Zahran H., Chahboune R., Moreno S., Bedmar E., AbdelFattah M., Yasser M., Mahmoud A. (2013) Identification of rhizobial strains nodulating Egyptian grain legumes. Int. Microbiol. 16: 157-163. 